\title{
Atmospheric ultrafine aerosol number concentration and its correlation with vehicular flow at two sites in the western Himalayan region: Kullu-Manali, India
}

\author{
Nand L Sharma ${ }^{1, *}$, Jagdish C Kuniyal ${ }^{2}$, Mahavir Singh ${ }^{3}$, Priyanka Sharma ${ }^{2}$, \\ Kesar Chand ${ }^{2}$, Ajay Kumar Negi ${ }^{2}$, Manum Sharma ${ }^{2}$ and Harinder Kumar Thakur ${ }^{2}$ \\ ${ }^{1}$ Department of Physics, Govt. Post Graduate College, Kullu 175 101, India. \\ ${ }^{2}$ G.B. Pant Institute of Himalayan Environment $\& 3$ Development, Himachal Unit, Mohal-Kullu 175 126, India. \\ ${ }^{3}$ Department of Physics, Himachal Pradesh University, Shimla 171 005, India. \\ *e-mail: nlsharmakullu@hotmail.com
}

The concentration of ultrafine aerosol particles of aitken and nucleation mode having size in the range of 1-20 nm was monitored with water-based Condensation Particle Counter. The monitoring was carried out from midnight-to-midnight in every alternate day on a fortnightly basis to represent summer, monsoon and winter (autumn) seasons of 2008 at Mohal (1154 m amsl) and Kothi (2530 m amsl) in Kullu-Manali area of the northwestern Himalayan region of India. The results indicate that diurnal pattern has faint bimodal structure with two peaks, one in morning and the other in evening at both the sites but it is not as distinct as found in plains. There is rather a constant particle density pattern of large magnitude consistent with vehicular movement from morning till evening. The monthly $24 \mathrm{~h}$ average particle density gradually picks up from January, increases rapidly in summer months and then decreases in monsoon season at Mohal but at Kothi it keeps on rising from April to October with a slight more increase in September. The particle density is more in summer than in monsoon season at Mohal, a trend opposite to plains. It may be due to the development of warm thermal layer on valley floor while a cold layer develops along snowy hilltops in winter leading to convection of fine particle up the slopes of valley during daytime. At Kothi, the trend is same as it is in continental plains but opposite to Mohal. The relatively more value of particle density in September and October at both the sites may be due to month long International Kullu Dussehra fair in the valley. The vehicular survey conducted agrees well with entire study period averaged diurnal variations and monthly $24 \mathrm{~h}$ averaged value of fine particle density. The average value of ultrafine particle density at each hour of a day for entire study period is $20369 \pm 1230 \mathrm{Ncm}^{-3}$ and $14389 \pm 1464 \mathrm{Ncm}^{-3}$ at Mohal and Kothi sites, respectively. The comparison with earlier results shows a significant increase indicating impact of vehicular onslaught on pure air of this hilly region.

\section{Introduction}

The study of atmospheric aerosols especially ultrafine mode is gaining importance in scientific community as numerous studies have demonstrated their association with health-related problems (Laden et al 2000; Oberdorster et al 1990; Pekkanen et al 1997) and climate changes (Tegen et al 1996; Ramanathan et al 2001). Further this study in the Himalayan region of Kullu-Manali is of particular

Keywords. Ultrafine particles; condensation particle counter; vehicular movement; correlation analysis; Kullu-Manali. 
interest as the ecology of the Himalaya is under serious threat from various forms of pollutants (Bostrom 2002). Moreover, the environmental factors of hilly areas are used as background levels for urban environments. The regional and synoptic characteristics of ultrafine aerosol and their significance are required to be investigated (Moorthy et al 1998, 2007, 2008). The ISRO-GBP program is a step in this direction but it mostly covers urban/semi-urban, oceans and coastal areas (Devara et al 1996; Moorthy et al 1997; Pant et al 2006). It mainly focuses on measurement of aerosol optical depth, Angstrom parameters, concentration and characterization of trace gases and radiation budgeting; while studies on ultrafine particles are being done at fewer stations and in hilly Himalayan regions of India, this study is non-existent (Mohan and Nigam 2003; Sellegri et al 2010). The anthropogenic activities such as increasing vehicular traffic due to increased tourism-related activities, biomass burning, forest fires (ignited by wrong notion of local habitat that it will produce rain and growth of animal fodder) and fuel wood burning for cooking and heating are the causes of concern for this so called zero pollutant level background region.

Particles in ambient air have size spanning from few nanometers to $100 \mu \mathrm{m}$ (Junge 1963; Prospero et al 1983). The particles of various sizes are generated by different sources in atmosphere and there is also a rapid process of recombination, nucleation, etc., going on in atmosphere. The particles of size $>2.5 \mu \mathrm{m}$ are called coarse particles which are mostly generated by dust resulting from excavation, blowing wind, etc. (Satheesh et al 2006). These particles of size $>2.5 \mu \mathrm{m}$ are generally removed by upper respiratory tract (Hansen et al 1984; Schwartz et al 1999) and are not much harmful to health. They are, therefore, also called respirable suspended particulate matter (RSPM). The suspended particles of size $<2.5 \mu \mathrm{m}$ are called fine particles. They are further classified as accumulation mode $(1$ to $0.1 \mu \mathrm{m})$ and fine particles of this range are dangerous as they penetrate into lungs and produce many respiratory problems (Wilson et al 1985; Berico et al 1997; Peters et al 1997). The still finer particle of size ranging from $0.1 \mu \mathrm{m}$ to few nanometer called ultrafine $[0.1-0.01 \mu \mathrm{m}]$ referred as Aitken mode (Aitken 1923 ) and $0.01-0.001 \mu \mathrm{m}$ referred as nucleation mode (Satheesh et al 2004) are most lethal to health as they penetrate deep into lungs during inhalation and may even act as nano antibiotic to kill human cells (Donaldson and Macnee 1998).

The nucleation mode particles are produced mainly through gas to particle conversion and slowly grow by condensation and coagulation into
Aitken mode and further into accumulation mode (Vakeva 2002).

The study of these so called ultrafine or atmospheric nanoparticles or Aitken nuclei is generating more and more interest in scientific community as most of the studies have revealed that particles originating from anthropogenic sources have size $<2.5 \mu \mathrm{m}$ (Querol et al 2001; Tiitta et al 2002). The role of these particles in producing depression, anxiety and many other neurological problems (Calderon et al 2002; Oberdorster et al 2004) is being investigated by scientists world over. In this paper, we present a number of studies of ultrafine particles and their correlation with vehicular traffic conducted at two sites in Kullu-Manali area during March to October 2008.

\section{Experimental setup and database}

\subsection{Site description}

The first site Mohal $\left(31^{\circ} 54^{\prime} \mathrm{N}, 77^{\circ} 07^{\prime} \mathrm{E}, 1154 \mathrm{~m}\right.$ amsl) is a flat region lying in middle of bowl shaped Kullu valley flanked from all sides by mountains of height ranging from 3000 to $5000 \mathrm{~m}$. This site is located on valley floor which facilitate this site to develop lower nocturnal temperature inversion layer (IBL) in summer and along higher snow covered mountaintops in winter, a trend opposite to plains (Lal 1997). The other site Kothi $\left(32^{\circ} 19^{\prime} \mathrm{N}\right.$, $77^{\circ} 11^{\prime} \mathrm{E}, 2530 \mathrm{~m}$ amsl) is the last inhabited village in this valley located at higher altitude on a mountain slope. It is on the way to famous snow sites of Gulaba and Rohtang Pass (3978 m amsl) and like most of continental plains lower nocturnal boundary layer might be formed here in winters. The river Beas originates from a place near Kothi and flows longitudinally through middle of the Kullu valley and National Highway-21 is just about $100 \mathrm{~m}$ from each experimental site. Native population of the area around first experimental site - Mohal was 18,306 while that of Kothi village was 567 . The population of the entire Kullu valley which constitutes Kullu and Manali subdivisions of Kullu district, part of Sadar Division of Mandi district was 221,858 (Census of India 2001).

According to RTO (regional transport office) data, about 30,000 vehicles of all kinds including two wheelers are registered till date and every year about 1000 new vehicles are registered at each subdivision of this valley. The vehicle survey conducted between $6 \mathrm{AM}$ and $6 \mathrm{PM}$ during the study period indicates that about 4800 vehicles at the first site while about 1500 vehicles at the second site ply on nearby $\mathrm{NH}-21$ on an average each day. At the second site, there are mostly tourist and army vehicles (ply only when Rohtang Pass 
remains opened) and here the traffic ceases during snowfall for most of winter months.

Being an important tourist destination of north India, thousands of tourists flock to Kullu-Manali area of the Himalayas during summer. In winter, local anthropogenic activity is low but tourist traffic is increasing as compared to previous years. It is evident from the fact that number of tourists increased from 0.13 million in 2004 to 0.55 million in 2008 according to DTO (District Tourism Officer - Kullu at Manali, H.P, India). The study area namely the Kullu valley has experienced tremendous growth in tourism over the last decade due to adverse condition in Kashmir as tourists diverted to this peaceful serine region (Kuniyal et al 2004). It is also evident from the Economic Survey, Govt. of Himachal Pradesh, India (http://himachal.gov.nic.in/economics/REPORTS/ EconomicSurveyofHP8-09.pdf) that from 2004 to 2008 , the total tourist traffic to the entire state of Himachal Pradesh increased from 6.55 to 9.75 million out of which Kullu-Manali alone hosted 2.12 million tourists in 2008 .

\subsection{Prevailing meteorology}

The Kullu valley is a rain-shadow belt receiving most of the rain during winter months. Heavy snowfall is witnessed in most of winter months at the second site but at first site mostly the adjoining hilltops are snow covered in winter while once or twice it falls at bottom of the valley also. The climate of the region has three distinct seasons; summer (March-June), monsoon (July-September) and relatively longer and harsh winter (October-February). Figure 1 shows meteorological conditions of site retrieved from Automatic Weather Station (AWS) present at the two sites.

The average temperature during all measurement days of 2008 at Mohal rose from $15.8^{\circ} \mathrm{C}$ in March to a maximum $26.2^{\circ} \mathrm{C}$ in July, thereafter it fell to $19.7^{\circ} \mathrm{C}$ in October while at Kothi temperature rose from $9.1^{\circ} \mathrm{C}$ in March to become maximum $20.5^{\circ} \mathrm{C}$ in June and thereafter it fell to $12.0^{\circ} \mathrm{C}$ in October. The temperature at Kothi on an average is about $6^{\circ} \mathrm{C}$ less than Mohal. Wind speed at Mohal gradually seems to decrease from $0.7 \mathrm{~m} / \mathrm{s}$ in March to $0.5 \mathrm{~m} / \mathrm{s}$ in August and thereafter increases slightly from $0.7 \mathrm{~m} / \mathrm{s}$ in September to $0.6 \mathrm{~m} / \mathrm{s}$ in October. The pattern of meteorological parameters at Kothi is similar but wind speed is considerably higher than at Mohal. At Kothi, wind speed decreases from $2.7 \mathrm{~m} / \mathrm{s}$ in March to $0.4 \mathrm{~m} / \mathrm{s}$ in August and thereafter increases to $0.6 \mathrm{~m} / \mathrm{s}$ in September and $1.1 \mathrm{~m} / \mathrm{s}$ in October with an exception in April when it remained very windy with an average wind speed of $3.3 \mathrm{~m} / \mathrm{s}$. The wind direction at Mohal is almost constant between $227^{\circ}$ and $229^{\circ}$ in summer months from March to June, but shows slight increase up to $244^{\circ}-256^{\circ}$ in monsoon season of July and August which thereafter decreases to $215^{\circ}-221^{\circ}$ in September and October at Mohal showing its flow mostly from south-west (from the Thar desert area of India) throughout the study period. Also at Kothi, the trend is same but wind direction remains between $164^{\circ}$ and $229^{\circ}$ showing its direction mostly from the south-east (from the Indo-Gangetic Plains of India). The humidity at Mohal shows an increase from $47 \%$ in March to $80 \%$ in August and thereafter it again decreases to $68 \%$ in October. At Kothi, the trend is similar with humidity rising from $52.6 \%$ in March
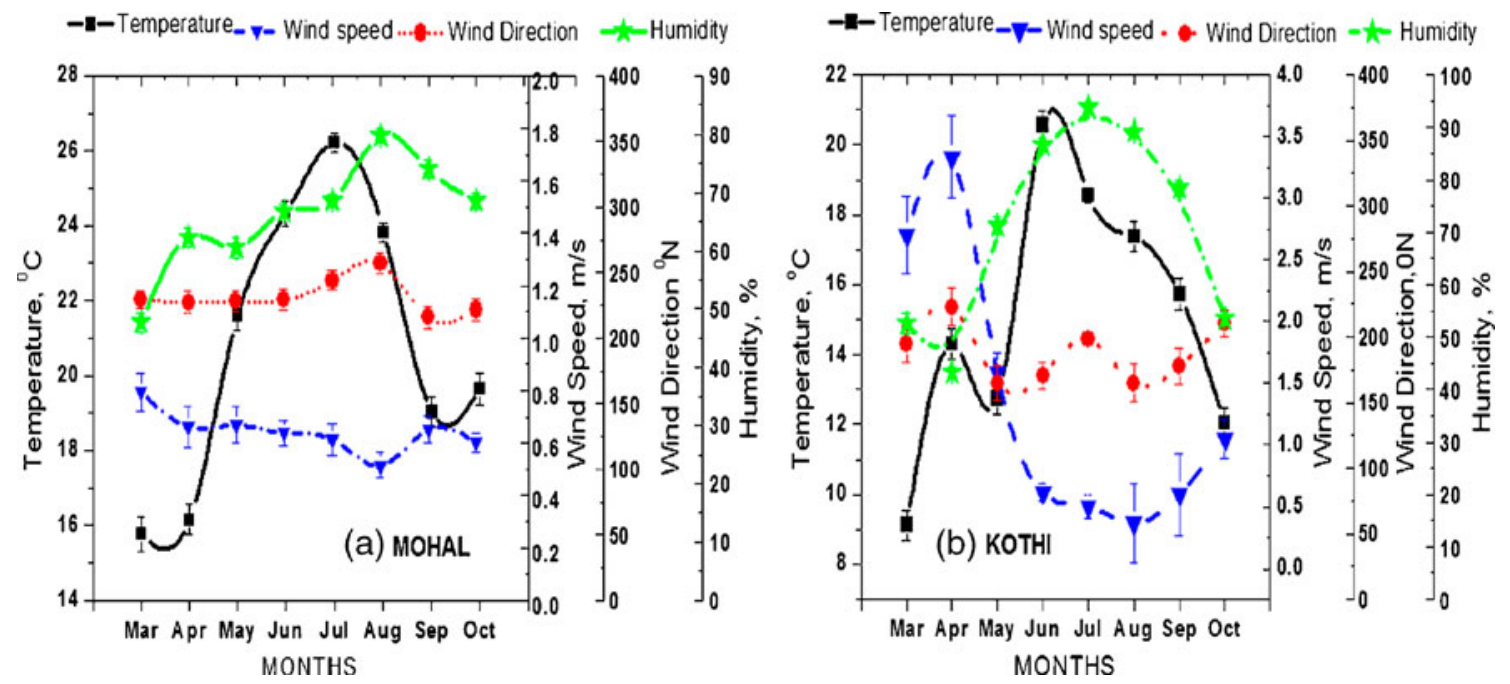

Figure 1. Meteorological conditions during ultrafine measurement days in 2008 at: (a) Mohal and (b) Kothi. 
to $93.8 \%$ in July which thereafter decreases gradually to $53.5 \%$ in October showing thereby that summer is less humid than monsoon but more humid than the onset of winter season. The present study is initiated keeping in view the increasing pressure of tourists and other activities such as forest fires, hydropower excavation works, etc., in the western Himalaya.

\subsection{Material and methods}

Regular measurements at every hour from midnight-to-midnight for summer, monsoon and a starting winter month of 2008 were taken at $3 \mathrm{~m}$ above ground level at above two sites using Condensation Particle Counter (CPC) of Polltech Instruments that can count particles of size ranging from 1 to $20 \mathrm{~nm}$. Due to having a single instrument for measurements, hourly measurement in an alternate day on fortnightly basis at each site was taken each month. As the hygroscopic nature of aerosol particles is size and composition specific, it was found that even non-hygroscopic aerosols exhibit response to condensation at increasing humidity (Tang 2000), so humidity above $85 \%$ is maintained in this instrument. It is well known that urban and continental air is rich in non-hygroscopic particles while the hilly and marine air is mostly full of hygroscopic particles (Svenningsson 1992). The polluted sites are found to have large fractions of non-hygroscopic particles than remote pristine sites (Vakeva 2002). Also, the efficiency and cut sizes performance for silver, ammonium sulphate and sodium chloride by water-based $\mathrm{CPC}$ are better than butanol-based CPC under increased streamline flow and condition of supersaturation (Biswas et al 2005; Mordas et al 2008), so we used water-based CPC for present study. Particle Counter Model PEM-PC2 (figure 2) is an advanced microprocessor-based instrument which is user programmable to facilitate automatic measurement and direct display of the number of particles per unit volume of the sampled air. PEMPC2 utilizes the well-known fact that under suitable operating conditions of supersaturation, small particles have the ability to act as condensation centres for water vapour. Upon condensation, these ultrafine particles grow in size leading to fog formation. The degree of fog gives a measure of particle concentration.

The particles from the atmosphere are sampled into the sampling chamber where moist blotting paper provides the saturated atmosphere. Adiabatic expansion of the air due to sudden connection of the sampling chamber to the evacuated auxiliary chamber through the quick opening valve results in supersaturation and consequent fog formation in the sampling chamber. Limited size discrimination can be achieved by controlling the partitioning volume in the auxiliary chamber. According to manufacturer, the instrument can count from $10^{2}$ to $10^{7}$ nuclei per $\mathrm{cm}^{3}$ with $10 \%$ of accuracy with suction rate of 10 lit. $/ \mathrm{min}$.

Hourly vehicular survey has also been conducted from $6 \mathrm{AM}$ to $6 \mathrm{PM}$ once every week on main

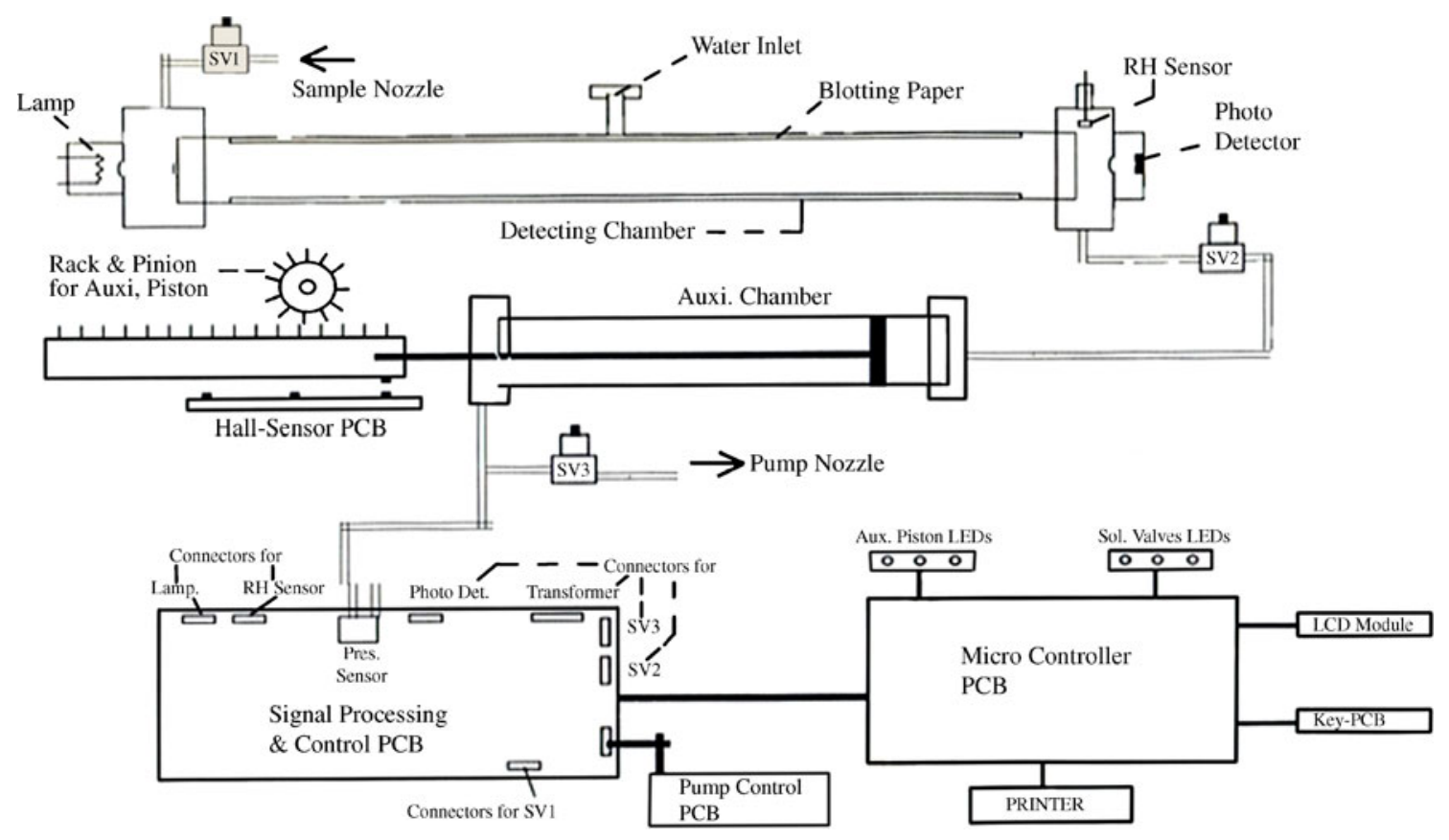

Figure 2. Schematic diagram of CPC instrument used for present study. 
NH-21 of valley at both the sites. The hourly vehicle flow averaged for a day, month and entire study period was calculated and correlated with particle density using well known Students $t$ distribution formula as:

$$
t=r \frac{\sqrt{(n-2)}}{\sqrt{\left(1-r^{2}\right)}},
$$

where $r$ is the correlation coefficient, $n$ is the number of data points, $n-2$ is the degree of freedom (Goyal and Sharma 1963). The $t$ thus calculated is used to find probability $P s$ of correlation outside the region of significance under two tailed column in T-table. The value of $P s$ is used to find percentage level of confidence. Hourly measurement of ultrafine particles of size 1-20 nm including hourly measurement of vehicular flow has been presented and analyzed in this paper.

\section{Results and discussions}

Figure 3 shows hourly variations of ultrafine particles of size 1-20 nm for 58 measurement days at Mohal and 57 days at Kothi from March to October 2008. For all months, midnight-to-midnight readings averaged at every hour have been taken. The dd-mm-yy-hr format has been used to plot particle density averaged at every hour of measurement day.

On close examination of hourly variation of particle density of all measurement days, we find that density as small as $200 \mathrm{~N} \mathrm{~cm}^{-3}$ to as large as $200,000 \mathrm{~N} \mathrm{~cm}^{-3}$ (at first site) and $100,000 \mathrm{~N} \mathrm{~cm}^{-3}$ (at second site) which was a trend found at various hilly forest sites (Kulmala et al 2007; Lehtipalo et al 2008). Also, it is seen that particle densities mostly lie below $40,000 \mathrm{~N} \mathrm{~cm}^{-3}$ at first site and below $20,000 \mathrm{~N} \mathrm{~cm}^{-3}$ at second site except
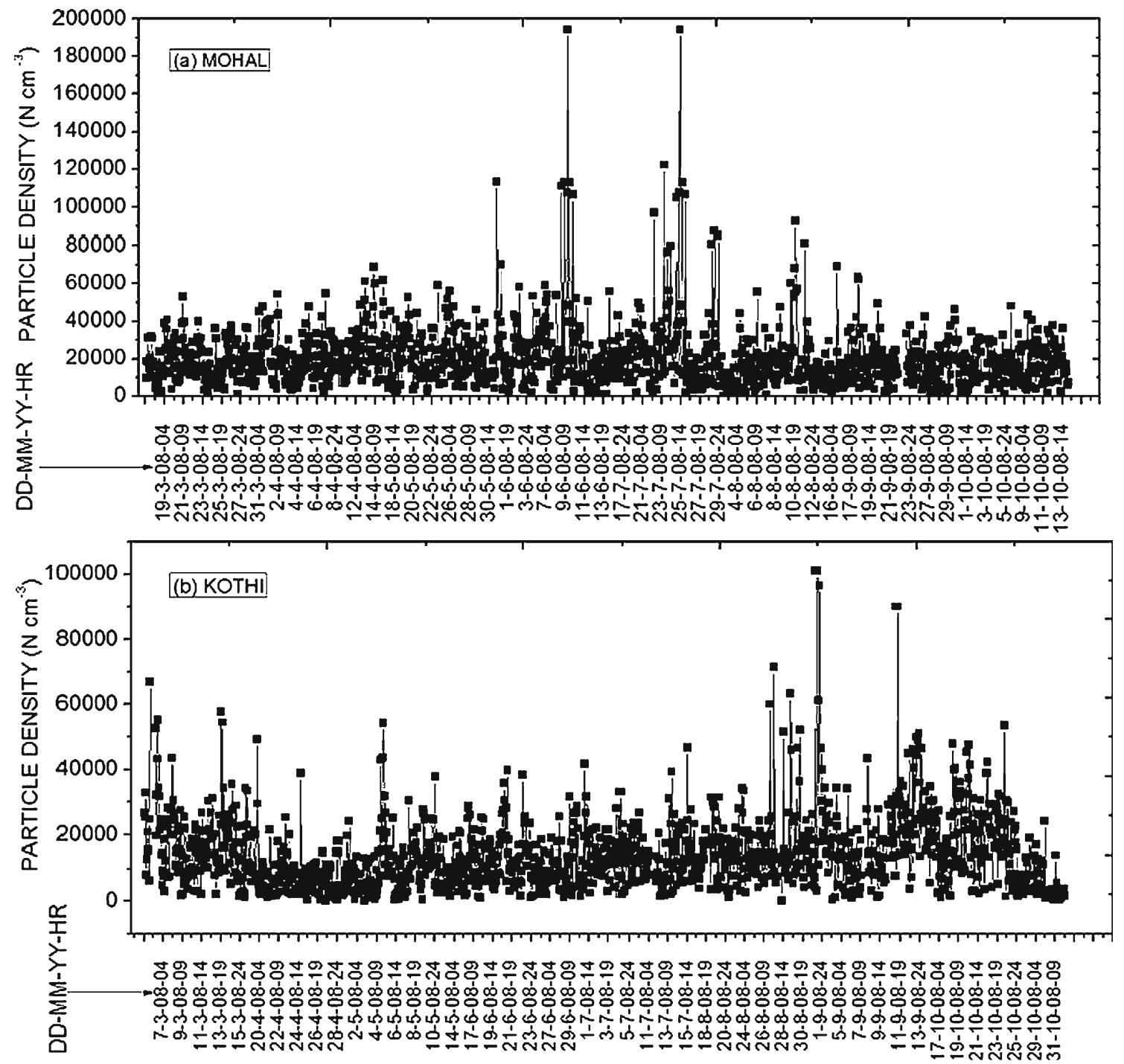

Figure 3. Time series of hourly variations of particle density of size 1-20 nm at: (a) Mohal and (b) Kothi. 
very few sudden peaks probably due to nucleation bursts.

Figure 4 shows hourly variation of particle density compared with 6 AM to 6 PM hourly vehicle flow at two sites for entire study period. From this figure, we find that particle concentration is almost constant throughout the day showing slight jumps in morning and evening during peak tourist times. At Mohal, it is observed that concentration is slightly high during peak traffic hours, i.e., concentration rises from 0500 hours, reaches peak around 0800 hours, then decreases slightly becoming minimum around 1400-1500 hours. It again picks up around 1600 hours reaching maximum around 2000-2100 hours while at Kothi it is also observed that concentration is slightly high during peak tourist traffic hours, i.e., 0900-1100 hours and then it decreases slightly becoming less around 1300 hours. It then again picks up reaching a maximum around 1400-1500 hours. So we have morning peak and evening peak earlier by about two hours due to late arrival of tourists and early departure from picnic spots and snow points near Kothi. These diurnal variations of the particle density are consistent with dynamics of the atmospheric boundary layer. There is negative temperature gradient in atmosphere up to end of troposphere where it gets inverted. Due to this negative temperature gradient, convection drifts polluted air upwards up to temperature inversion layer present at the end of troposphere whose height keep on rising with the advancing of day (Lal 1997). This height is characteristic of place and other atmospheric conditions like snow, clouds, sunshine, humidity, temperature of environment, etc. This layer is lower in winter than in summer in continental plain regions while in mountains this layer is higher than in the plains (Haurwitz and Austin 1944). By late afternoon, this inversion layer rises to its maximum height. After sunset cold surface of the earth leads to lowering of this layer and with advancing of night the nocturnal inversion layer reaches near the earth's surface.

Figure 4 also shows that relation of particle density with vehicular traffic is significant. From morning till evening, there is continuous flow of tourists and local traffic and similarly particle density is almost same from morning till evening except faint jumps at traffic rush hours. The rise of particle density in morning rush hours is due to increased vehicular rush and low height of inversion layer. As the day advances, the inversion layer deforms and rises to greater heights till evenings provided day is warm while traffic rush also becomes slightly low by afternoon. Both these factors lower the particle density by afternoons. By the evening, the earth's surface starts becoming cold and so the mixing layer drifts downwards slowly. The traffic (a) MOHAL
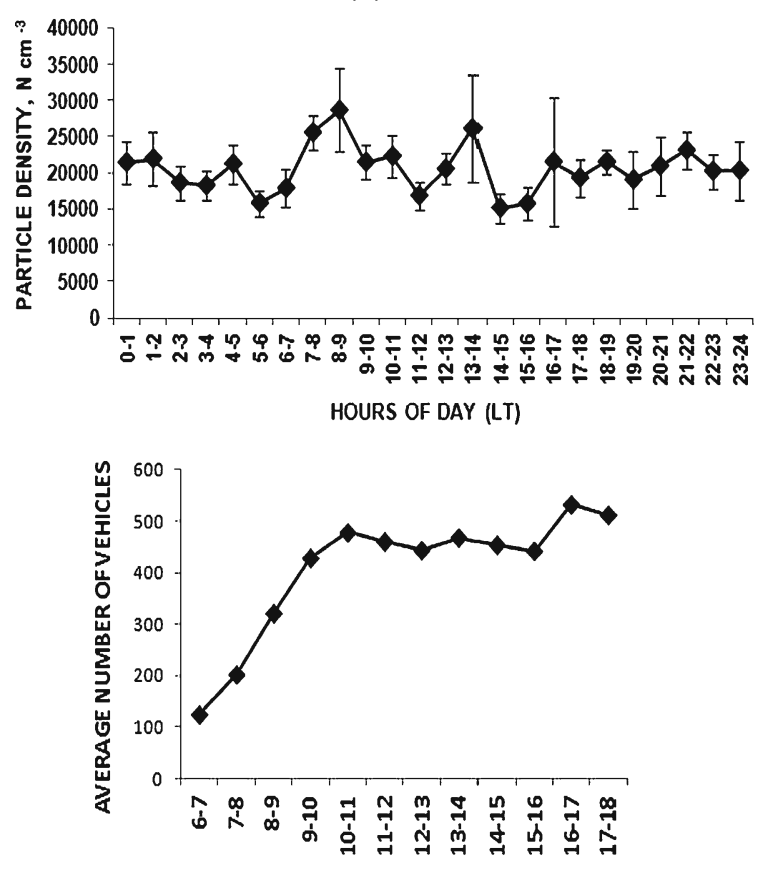

HOURS OF DAY (LT) (b) KOTHI
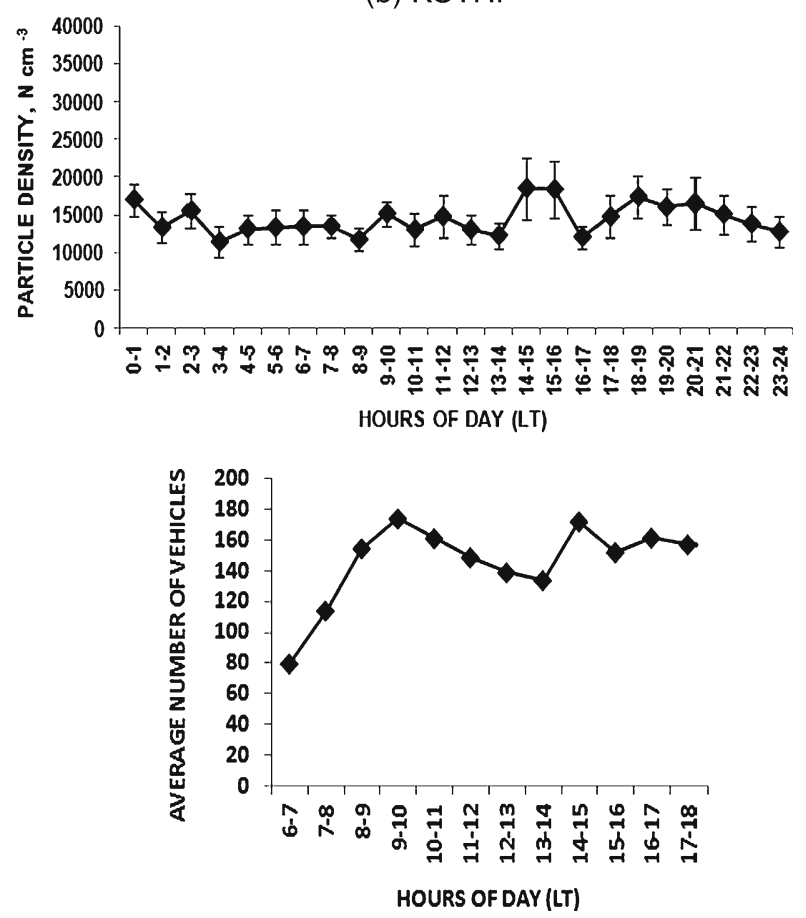

Figure 4. Average hourly variations of: (a) particle density and (b) vehicle flow for entire study period. 
rush slightly increases as people from office, school, etc., return. Both these factors again slightly raise the particle density.

At Mohal, average hourly particle density for the eight months study period is found fluctuating around 20,000 particles per $\mathrm{cm}^{3}$ for most of the hours of a day with maximum average particle density of $28644 \pm 4541 \mathrm{~N} \mathrm{~cm}^{-3}$ at 0800 hours and minimum density with $15106 \pm 1901 \mathrm{~N} \mathrm{~cm}^{-3}$ at 1400 hours. At Kothi, average hourly particle density for the same study period is found fluctuating around 14,000 particles per $\mathrm{cm}^{3}$ with maximum to be $18512 \pm 4094 \mathrm{~N} \mathrm{~cm}^{-3}$ at 1400 hours and minimum density to be $11418 \pm 2095 \mathrm{~N} \mathrm{~cm}^{-3}$ at 0300 hours. These results are similar to the trend found in flat hill stations like Malampuzha and Sulthan Bathery of Kerala (Varikoden et al 2008) where annual hourly particle density of particles of size $1-0.01 \mu \mathrm{m}$ during 2008 was found to be fluctuating around 5000 and 15,000 particles per $\mathrm{cm}^{3}$. But these values are higher than the very few available Himalayan hill region studies (Kivekas et al 2009; Komppula et al 2009) that reported 3280 and 3480 particles per $\mathrm{cm}^{3}$ at Mount Waliguan (3816 m amsl) and Mukteshwar $(2180 \mathrm{~m}$ amsl), respectively. The reason for this could be more height of these sites from sea level and fewer tourists visiting these areas. At foreign hilly sites like Tomsk (rural) and Listyanka (semi-rural), the annual hourly concentration of ultrafine particles were reported to fluctuate around 2500 and 5000 particles per $\mathrm{cm}^{3}$ (Maso et al 2008). Our values are not only considerably greater than these rural foreign sites but also are higher than the values observed in some cities of Europe like Helsinki, Stockholm and Augsburg where annual ultrafine particle density averaged is around 10,000 particles per $\mathrm{cm}^{3}$ (Aalto et al 2005). When particle density at all hours of various measurement days of a month are further averaged, we get monthly variation at two sites along with monthly vehicle flow as shown in figure 5 .

It shows that particle density is more in summer and less in monsoon and beginning of winter season at the first site, while at the second site an opposite trend is observed. It may be pointed out that at first site, the trend is opposite, while at second site it is same as found at most of continental plains, i.e., density is higher in winter than in summer (Komppula et al 2003; Tunved et al 2003). The reason for this opposite trend could be the occurrence of snowfall and hence low temperature along mountain tops during monsoon and beginning of winter than in valley floor which leads to formation of higher inversion layer along mountain tops. It leads to convection of pollutant particles up to the mountain tops (Trewartha 1968). So the particle density will be more along mountain top and less on valley floor. As first site is on valley floor and second site is closer to the mountain top, so
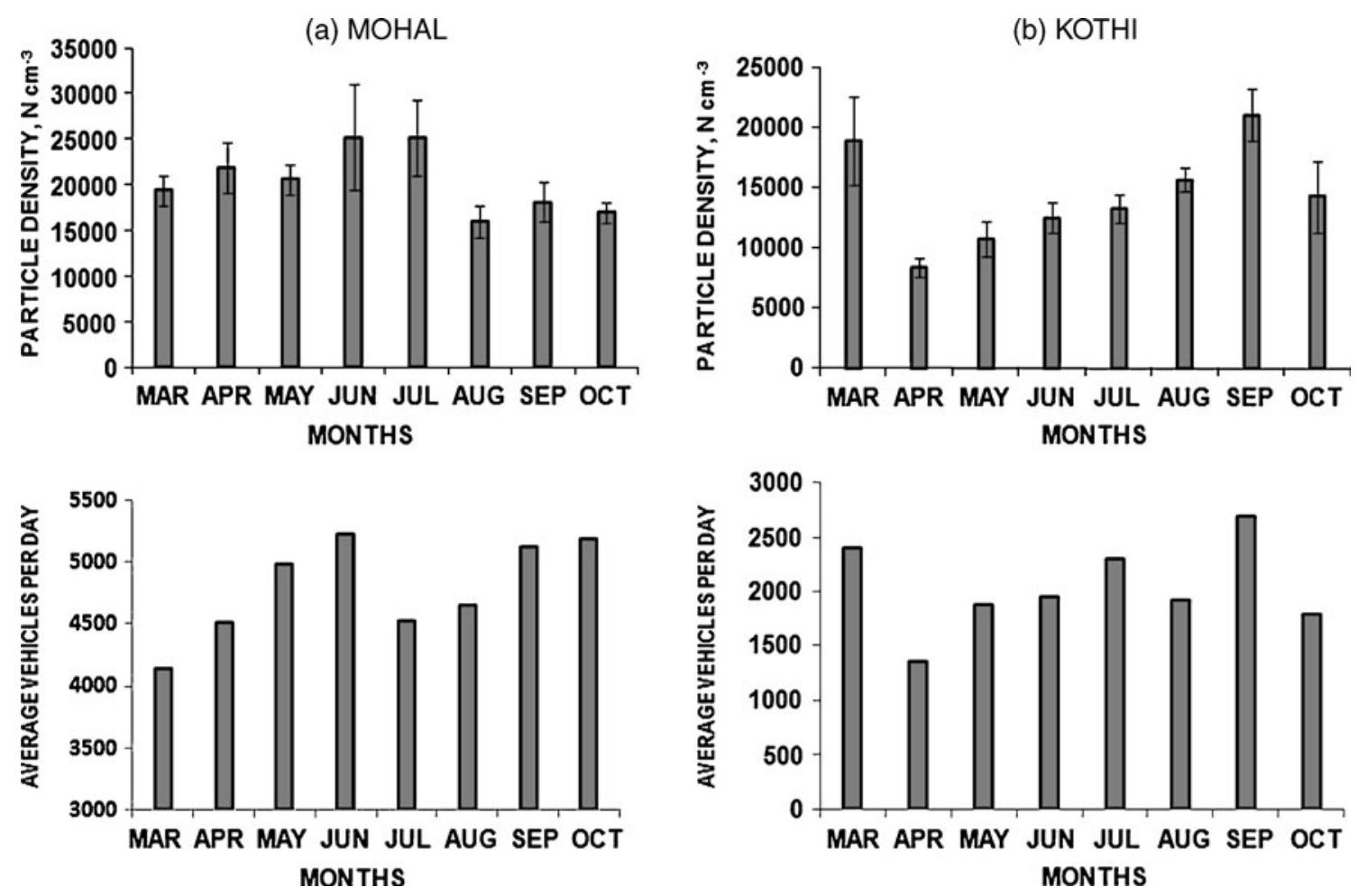

Figure 5. Monthly variations of average value of: (a) $24 \mathrm{~h}$ averaged particle density and (b) vehicles flow per day. 
particle density is found less in monsoon and beginning of winter season than in summer at first site and opposite trend is observed at second site due to usual shallow inversion layer (Rodriguez et al 2005). The earlier studies (Sharma et al 2009) on nano/aitken particles of three size modes at first site for all seasons of a year are in line with this trend.

Also, high frequency of nucleation bursts during summer at first site and that in monsoon and beginning of winter at second site could be the reason for more particle density during these seasons (Tunved et al 2006). This type of reverse trend has been found in some hill stations like puy de Dome, France (Venzac et al 2009). The highest monthly 24-hour averaged particle density was found to be $25122 \pm 4304 \mathrm{~N} \mathrm{~cm}^{-3}$ in July at first site and $21091 \pm 2845 \mathrm{~N} \mathrm{~cm}^{-3}$ in September at second site. While the same lowest value of particle density was found to be $16017 \pm 2587 \mathrm{~N} \mathrm{~cm}^{-3}$ in August at first site and $8462 \pm 112 \mathrm{~N} \mathrm{~cm}^{-3}$ in April at second site. The 24-hour average for the entire study period was found to be $20369 \pm 1230$ and $14389 \pm 1464 \mathrm{~N} \mathrm{~cm}^{-3}$ at first and second sites, respectively. It may be pointed out that earlier studies conducted in May and June of 1996, 1999 and 2000 yielded 24-hour average particle density as $3990 \mathrm{~N} \mathrm{~cm}^{-3}$ and $1350 \mathrm{~N} \mathrm{~cm}^{-3}$ at first and second sites (Gajananda et al 2005) which are considerably less than the present values.

This monthly variation of particle density is also consistent with monthly vehicular movement data as shown in bottom panel of figure 5 ( $\mathrm{a}$ and $\mathrm{b}$ ). The comparison shows almost the same trend of particle density and vehicular movement for various months of study period at both the sites. At first site, both rises from March to June and then both have small and increasing values in monsoon and beginning of winter months except July. Higher value of particle density in monsoon months of July can be due to foggy conditions (Wang et al 2009) and frequency of large number of NBs might also be one of the reasons. In August, comparatively low value of particle density can be due to the frequent rains leading to wash-out effect and scavenging of fine particles to form cloud condensation nuclei (Satheesh 2002). The abnormal rise in September and October in vehicular movement may be due to the month-long international Kullu Dussehra fair which started on 6 October, 2008; the same abnormal rise during these months has been found in particle density also. The correlation analysis between monthly particle density and monthly vehicular flow shows good positive correlation coefficient as $0.7603(P s<0.20, C L>$ $80 \%$ ) for summer and $0.7711(P s<0.20, C L>$ $80 \%$ ) for monsoon and beginning of winter season if the abnormal value of July month is excluded.
At second site, almost the same trend of particle density and vehicular movement is also observed. Both rise from April to October with a slight increase in the month of September. The abnormal rise of particle density in March may be due to use of fuel wood for cooking and heating purposes and increased tourists flow to see the snowfall. In September and October, particle density is also abnormally large at this site due to more vehicular movement as a result of month long international Kullu Dussehra festival in the Kullu valley. The correlation analysis between monthly particle density and monthly vehicular flow shows high positive correlation coefficient value of 0.9478 $(P s<0.05, C L>95 \%)$ for summer and a good correlation coefficient of $0.7172(P s<0.20, C L>$ $80 \%$ ) for monsoon and beginning of winter season.

\section{Conclusions}

Close examination of the above analysis yields the following conclusions:

- The ultrafine particle density at various hours of study period mostly lie below $40000 \mathrm{~N} \mathrm{~cm}^{-3}$ at low altitude site and below $20000 \mathrm{~N} \mathrm{~cm}^{-3}$ at high altitude site except few peaks due to nucleation bursts.

- The hourly variation of particle density for the entire study period was found to be faint bimodal at both the sites. First peak is observed around 0600-0800 and second at 2000-2100 at low altitude site while at high altitude site they occur at $0900-1100$ and 1400-1500, respectively. At low altitude, Mohal it is found to be fluctuating around $20000 \mathrm{~N} \mathrm{~cm}^{-3}$ at various hours of a day while at high altitude site Kothi, it is found to be $14000 \mathrm{~N} \mathrm{~cm}^{-3}$ which are not only high as compared to previous studies conducted at this site but also high in comparison to various other Indian and foreign hilly sites.

- The daily averaged value of particle density when averaged again for the various measurement days of month, it was found to be gradually building up from March onward becoming large in June which then reduces with an exception of not much decrease in September and October at low altitude site Mohal. At high altitude site Kothi, it increases from April to October with a slight increase in the month of September. The abnormal rise of particle density in March at Kothi may be due to the use of fuel wood for cooking and heating purposes and increased tourists flow to see the snowfall while abnormally large particle density at both sites in September and October may be due to the month-long international Kullu Dussehra fair in the valley. 
- The build up is more pronounced in summer than in monsoon and beginning of winter season at low altitude site; a trend opposite to continental plains. But at high altitude site, same trend as in continental plains is found, i.e., low particle density in summer and high in monsoon and beginning of winter seasons. The particle density has also a good positive correlation with vehicular movement data on hourly as well as on monthly basis.

It can therefore be concluded that nucleation (nanoparticles) and Aitken nuclei concentration from petrol and diesel exhausts and many other sources have increased considerably in this part of the northwestern Indian Himalaya and stringent remedial measures are needed to be taken up.

\section{Acknowledgements}

The authors are thankful to the Director of G.B. Pant Institute of Himalayan Environment and Development, Kosi-Katarmal, Almora (Uttarakhand) for providing facilities to conduct the present study. They are also thankful to Registering and Licensing Authority (RLA) and Regional Transport Office (RTO) and District Tourism Officer (DTO) of Kullu district for their valuable help in providing total vehicles registered and tourist arrival data in Kullu valley.

\section{References}

Aalto P, Hameri K, Paatero P, Kulmala M, Forastiere F, Cattani G, Marconi A, Cyrys J, VonKlot S, Zetzsche K, Peters A, Bouso L, Castano G, Palacio J A, Sunyer J, Lanki T, Pekkanen J, Sjoval B, Berglind N, Bellander T and Nyberg F 2005 Aerosol number concentration measurements in five European cities using TSI-3022 condensation counter over three-year period during health effects of air pollution on susceptible subpopulations; J. Air Waste Manage. Assoc. 55(8) 1064-1076.

Aitken J 1923 Collection of scientific papers (London \& New York: Cambridge University Press) p. 13.

Berico M, Luccinni A and Formignani M 1997 Atmospheric aerosols in an urban area - Measurement of TSP \& $\mathrm{PM}_{10}$ standards and pulmonary deposition assessments; Atmos. Environ. 31 3659-3665.

Biswas S, Fine P M, Gellar M D, Hering S V and Sioutas C 2005 Performance evaluation of recently developed water based condensation particle counter; Aerosol Sci. Technol. 39 419-427.

Bostrom N 2002 Existential Risks: Analyzing human extinction scenario and related hazards; J. Evol. Tech. 9(4.7) $1-30$.

Calderon G L, Azzarelli B, Acuna H, Garcia R, Gambling T M, Villarraeal C A and Recastle B 2002 Air pollution and brain damage; Toxicol. Pathol. 30 373-389.

Census of India 2001 Provisional Population Totals - Part2; Director of Census Operation, Govt. of Himachal Pradesh, Shimla, India, pp. 1-79.
Devara P C S, Pandithurai G, Raj P E and Sharma S 1996 Investigations of aerosol optical depth variations using spectroradiometer at urban station, Pune, India; J. Aerosol Sci. 27 621-632.

Donaldson K and Macnee X W 1998 Ultrafine (nanometre) particle mediated lung injury; J. Aerosol Sci. 6 553-560.

Gajananda Kh, Kuniyal J C, Momin G A, Rao P S P, Safai P D and Ali K 2005 Trend of atmospheric aerosols over north western Himalayan region, India; Atmos. Environ. 39(27) 4817-4825.

Goyal J K and Sharma J N 1963 Mathematical Statistics (Krishna Prakashan Mandir, Meerut, India), pp 378-476 \& tables VI, X.

Hansen A D A, Rosen H and Novakov T 1984 The Aethalometer - An instrument for the real-time measurement of optical absorption by aerosol particles; Sci. Tot. Environ. 36 191-196.

Haurwitz B and Austin J M 1944 Climatology (New York: McGraw-Hill Book Company, Inc.), p. 38.

Junge C E 1963 Air chemistry and radioactivity (New York, USA: Academic Press Inc.), pp 11-208.

Kivekas N, Sun J, Zhan M, Kerminen V M, Hyvarinen A, Komppula M, Viisanen Y, Hong N, Zhang Y, Kulmala M, Zhang X C, Deli-Geer and Lihavainen H 2009 Long term particle size distribution measurements at Mount Waliguan, a high-altitude site in inland China; Atmos. Chem. Phys. 9 5461-5474.

Komppula M, Lihavainen H, Hatakka J, Paatero J, Aalto P, Kulmala M and Viisanen Y 2003 Observations of new particle formation and size distributions at two different heights and surroundings in subarctic area in northern Finland; J. Geophys. Res.-Atmos. 108(D9) 4295.

Komppula M, Lihavainen H, Hyvarinen A P, Kerminen V M, Panwar T S, Sharma V P and Viisanen Y 2009 Physical properties of aerosol particles at a Himalayan background site in India; J. Geophys. Res. 114 D12202, doi: 10.1029/2008JD011007.

Kulmala M, Riipinen I, Sipilia M, Manninen H, Petaja T, Junninen H, Dal Maso M, Mordas G, Mirme A, Vana M, Hirsikko A, Laakso L, Harrison R M, Hansson I, Leung C, Lehtinen K E J and Kerminen V M 2007 Towards direct measurement of atmospheric nucleation, Science 318 89-92.

Kuniyal J C, Vishvakarma S C R, Badola H K and Jain A P 2004 Tourism in Kullu valley: An environmental assessment (Bishen Singh \& Mohindra Pal Singh, Dehradun, India), pp 1-210.

Laden F, Neas L M, Dockery D W and Schwartz J 2000 Association of fine particulate matter from different sources with daily mortality in six US cities; Environ. Health. Persp. 108 941-947.

Lal D S 1997 Climatology (Sharda Pustak Bhawan, Allahbad, India), pp 65-76.

Lehtipalo K, Sipila M, Riipinen I, Nieminen T and Kulmala M 2008 Analysis of atmospheric neutral and charged molecular clusters in Boreal forest using pulse height CPC; Atmos. Chem. Phys. Discuss. 8 20,661-20,685.

Maso M D, Sogacheva L, Anisimov M P, Arshinov M, Baklanov A, Belan B, Khodzher T V, Obolkin V A, Vlasov A, Zagaynov V A, Lushnikov A, Riipinen I, Kerminen V M and Kulmala M 2008 Aerosol particle formation events at two Siberian stations inside Boreal forest; Boreal Environ. Res. 13 81-92.

Mohan M and Nigam S K 2003 Modeling technique for fog prediction: A review; Indian J. Environ. Protec. 23(5) 481-488.

Moorthy K K, Satheesh S K and Krishna Murthy B V 1997 Investigations of marine aerosols over the Tropical Indian Ocean; J. Geophys. Res. 102 18,827-18,842. 
Moorthy K K, Satheesh S K and Krishna Murthy B V 1998 Characteristics of spectral optical depths and size distributions of aerosols over Tropical Oceanic Regions; J. Atmos. Sol. Terr. Phys. 60(10) 981-992.

Moorthy K K, Babu S S and Satheesh S K 2007 Temporal heterogeneity in aerosol characteristics and the resulting radiative impact at a tropical coastal station - II: Direct short wave radiative forcing; Ann. Geophys. 25 2308-2320.

Moorthy K K, Satheesh S K, Babu S S and Dutt C B S 2008 Integrated campaign for aerosols, gases and radiation budget (ICARB): An Overview; J. Earth Syst. Sci. 117 243-262.

Mordas G, Manninen H E, Petoja T, Aalto P P, Hameri K and Kulmala M 2008 On operation of the ultrafine water based CPC and comparison with other models; Aerosol Sci. Technol. 42 152-158.

Oberdorster G, Ferin J, Penney D P, Soderholm S C, Gelein R and Piper H C 1990 Increased pulmonary toxicity of ultrafine particles to lung lavage studies; J. Aerosol Sci. 17 361-364.

Oberdorster G, Sharp Z, Atudorei V, Eder A, Gelin R, Kreyling W and Cox C 2004 Translocation of inhaled ultrafine particles to brain; Inhal. Toxicol. 16 437-445.

Pant P, Hegde P, Dumka U C, Saha A, Srivastava M K and Sagar R 2006 Aerosol characteristics at a high-altitude location during ISRO-GBP Land Campaign-II; Curr. Sci. 91 1053-1061.

Pekkanen J, Timonen K L, Ruuskanen J, Reponen A and Mirme A 1997 Effects of ultrafine and fine particles in urban air on peak expiratory flow among children with asthmatic symptoms; Environ. Res. 74 24-33.

Peters A, Wichmann H E, Tuch T, Heinrich J and Hyder J 1997 Respiratory effects are associated with the number of ultrafine particles in human respiratory tract; $A m$. J. Respir. Crit. Care Med. 155(4) 1376-1383.

Prospero J M, Charlson R J, Mohnen V, Jaenicke R, Delany A C, Moyers S, Zoller W and Rahn K 1983 The atmospheric aerosol system: An overview; Rev. Geophys. 21 1607-1629.

Querol X, Alastuey A, Rodriguez S, Plana F, Ruiz C R, Cots N, Massakgul G and Puig O $2001 \mathrm{PM}_{10}$ and $\mathrm{PM}_{2.5}$ source apportionment in the Barcelona Metropolitan area, Catelonia, Spain; Atmos. Environ. 35 6407-6419.

Ramanathan V, Crutzen $\mathrm{P}$ J, Kiehl J $\mathrm{T}$ and Rosenfeld D 2001 Aerosol, climate and the hydrological cycle; Science 294 2119-2124.

Rodriguez S, Van Dingenen R, Putaud J P, Martins-Dos Santos S and Roselli D 2005 Nucleation and growth of new particles in the rural atmosphere of Northern Italy Relationship to air quality monitoring; Atmos. Environ. 39(36) 6734-6746.

Satheesh S K 2002 Aerosol radiative forcing by Indian Ocean aerosols: Effect of cloud and surface reflection; Ann. Geophys. 20 2105-2109.

Satheesh S K, Moorthy K K and Srinivasan J 2004 Introduction to aerosols and impacts on atmosphere: Basic concepts, ISRO-GBP Scientific Report; SR 05, pp $1-100$.

Satheesh S K, Deepshikha S and Srinivasan J 2006 Impact of dust aerosols on earth-atmosphere clear-sky albedo and its short wave radiative forcing over African and Arabian regions; Int. J. Remote Sens. 27 1691-1706.

Schwartz J, Norris G, Larson T, Sheppard L, Claiborne C and Koenig J 1999 Episodes of high coarse particle concentrations are not associated with increased mortality; Environ. Health Perspect. 107(5) 339-342.

Sellegri K, Laj P, Venzac H, Boulon J, Picard D, Villani P, Bonasoni P, Marinoni A, Cristofanelli $\mathrm{P}$ and Vuillermoz E 2010 Seasonal variations of aerosol size distributions based on long-term measurements at the high altitude Himalayan site of Nepal Climate Observatory-Pyramid (5079 m), Nepal; Atmos. Chem. Phys. 10 6537-6566.

Sharma N L, Kuniyal J C, Singh M, Negi A K, Singh K and Sharma P 2009 Number concentration characteristics of ultrafine aerosols (atmospheric nanoparticles/aitken nuclei) during 2008 over western Himalayan region Kullu-Manali, India; Indian J. Radio Space Phys. 38 326-337.

Svenningsson B 1992 Hygroscopic growth of aerosol particles and and its relation to nucleation scavenging in clouds, $\mathrm{PhD}$ dissertation, University of Lund Sveden.

Tang I N 2000 Phase transformation and growth of hygroscopic aerosols: Aerosol chemical process in the environment (ed.) Spurny K R, Lewis Publishers, 61-80.

Tegen I, Lacis A and Fung I 1996 The influence of mineral aerosol from distribution soils on the global radiation budget; Nature 380 419-422.

Tiitta P, Raunema T, Tissari J, Yli-Tuomi T, Leskinen A, Kukkonen J, Harkonen J and Karppinen A 2002 Measurements and modeling of PM2.5 concentration near a major road in Kuopio, Finland; Atmos. Environ. 36 4057-4068.

Trewartha G T 1968 An Introduction to Climate (New York: McGraw-Hill Book Company, Inc.), p. 40.

Tunved P, Hansson H-C, Kulmala M, Aalto P, Viisanen Y, Karlsson H, Kristensson A, Swietlicki E, Dal Maso M, Strom J and Komppula M 2003 One year boundary layer aerosol size distribution data from five Nordic background stations; Atmos. Chem. Phys. 3 2183-2205.

Tunved J, Korhenen H, Strom J, Hansson H C, Lehtinen K E J and Kulmala M 2006 Is nucleation capable of explaining observed aerosol integral number increase during southerly transport over Scandinavia? Tellus B 58(2) 129-140.

Vakeva M 2002 Studies of hygroscopic properties of nucleation mode particles; Report Series in Aerosol Science $\mathbf{5 5}$ 1-29, ISBN 952-5027-32-5.

Varikoden H, Sasikumar V, Sampath S, Muralidas S and Mohankumar G 2008 Diurnal and spatial variation of condensation particles in Kerala, South India; Curr. Sci. 94(2) 233-237.

Venzac H, Sellegri K, Villani P, Picard D and Laj P 2009 Seasonal variation of aerosol size distributions in the free troposphere and residual layer at the puy de Dome station, France; Atmos. Chem. Phys. 9 1465-1478.

Wang Y, Che H, Ma J, Wang Q, Shi G, Chen H, Goloub $\mathrm{P}$ and Hao X 2009 Aerosol radiative forcing under clear, hazy, foggy, and dusty weather conditions over Beijing, China; Geophys. Res. Lett. 36 L06804, doi: 10.1029/2009GL037181.

Wilson F J, Hiller F C, Wilson J D and Bone R C 1985 Quantitative deposition of ultrafine particles in human respiratory tract; J. Appl. Physiol. 58(1) 223-229. 